\title{
New Actors and Alliances in Development
}

\author{
Richey, Lisa Ann; Ponte, Stefano
}

Document Version

Accepted author manuscript

Published in:

Third World Quarterly

DOI:

10.1080/01436597.2014.868979

Publication date:

2014

License

Unspecified

Citation for published version (APA):

Richey, L. A., \& Ponte, S. (2014). New Actors and Alliances in Development. Third World Quarterly, 35(1), 1-21. https://doi.org/10.1080/01436597.2014.868979

Link to publication in CBS Research Portal

\section{General rights}

Copyright and moral rights for the publications made accessible in the public portal are retained by the authors and/or other copyright owners and it is a condition of accessing publications that users recognise and abide by the legal requirements associated with these rights.

Take down policy

If you believe that this document breaches copyright please contact us (research.lib@cbs.dk) providing details, and we will remove access to the work immediately and investigate your claim. 


\section{New Actors and Alliances in Development Lisa Ann Richey and Stefano Ponte}

Journal article (Post print version)

Cite: New Actors and Alliances in Development. / Richey, Lisa Ann; Ponte, Stefano.In: Third World Quarterly, Vol. 35, No. 1, 13.02.2014, p. 1-21.

This is an Accepted Manuscript of an article published by Taylor \& Francis in Third World Quarterly on 08 August 2016, available online:

http://www.tandfonline.com/10.1080/01436597.2014.868979

Uploaded to Research@CBS: May 2017 


\title{
New Actors and Alliances in Development
}

\author{
Lisa Ann Richey ${ }^{\mathrm{a}}$ and Stefano Ponte ${ }^{\mathrm{b}}$ \\ ${ }^{a}$ Department of Society and Globalisation, Roskilde University, Denmark \\ ${ }^{\mathrm{b}}$ Department of Business and Politics, Copenhagen Business School, Denmark
}

\begin{abstract}
New Actors and Alliances in Development brings together an interdisciplinary group of scholars exploring how development financing and interventions are being shaped by a wider and more complex platform of actors than usually considered in the existing literature. The contributors also trace a changing set of key relations and alliances in development - those between business and consumers; NGOs and celebrities; philanthropic organizations and the state; diaspora groups and transnational advocacy networks; ruling elites and productive capitalists; and between 'new donors' and developing country governments. Despite the diversity of these actors and alliances, several commonalities arise: they are often based on hybrid transnationalism and diffuse notions of development responsibility; rather than being new per se, they are newly being studied as engaging in practices that are now coming to be understood as 'development'; and they are limited in their ability to act as agents of development by their lack of accountability or pro-poor commitment. The articles in this collection point to images and representations as increasingly important in development 'branding' and suggest fruitful new ground for critical development studies.
\end{abstract}

Keywords - actors, alliances, relations, critical development studies

\section{Introduction}

This special issue examines the rise of new actors and the configuration of new alliances in development financing and intervention. The nexus of international development has seen a marked shift from public aid to private flows, and from primarily North-South relations to multiple polarities of emerging economies, nonDAC donors and the ubiquitous debate on China in Africa. The contributions in this collection move beyond the analysis of 'traditional' actors - such as governments, international organizations and NGOs - to highlight how business, consumers, celebrities, philanthropic organizations, diaspora groups, elites and 'non-traditional' state actors work as 'legitimate' development actors to configure the ideas and financing for international development. In the process, new spaces are shaped, both 
opened and constricted, by a changing set of relations and alliances - those between business and consumers; NGOs and celebrities; philanthropic organizations and the state; diaspora groups and transnational advocacy networks; ruling elites and productive capitalists; and between 'new donors' and developing country governments.

Not all these actors and alliances examined in this special issue are strictly 'new', as they may have taken new configurations or are operating in new ways, but many are only recently considered as the targets of study by international development scholars. As concluded by Corbridge in his seminal piece on the field: 'Development studies . . . cannot escape the dirty worlds of practical policy-making which lend it a reason for being, and which render it impotent, apolitical or supportive of a series of interventions that disempower and even infantilize "the poor". 1 Central concerns of authors in this collection involve the agency of actors whose practices are constituting new forms of engagement in development processes, as well as the structures of constraint and opportunity that shape their engagement. Reflecting on the importance of history for contemporary development policy, ${ }^{2}$ the articles included in this special issue strive to understand difference historically and highlight critical changes, but also continuities. They document how these actors and alliances are arising, their potential and limitations, the subjectivities they (re)create and the reconfiguration of worthy recipients of 'help' they stimulate. In doing so, this collection stakes a claim for understandings of development that are critically engaged, while remaining informed by theoretical, historical and empirical research.

Development scholars wedding critical theory insights with international development practices have argued that the perpetuation of universal notions of development are misguided, as these concepts are inextricably linked to the logics of global capitalism. ${ }^{3}$ This 'development' apparatus was described in Ferguson's classic book as 'an anti-politics machine, depoliticizing everything it touches, everywhere whisking political realities out of sight, all the while performing, almost unnoticed, its own pre-eminently political operation of expanding bureaucratic state power'. ${ }^{4}$ At its most poignant, critical development studies was able to meticulously document how development worked in specific instances to expand the tentacles of the great liberal villain: the state. Then, as neoliberalism and its accompanying structural adjustments 
emasculated state after state in both North and South, and replaced them with markets, development's critical impulse subsided. Since its peak in the 1990s, critical development studies has become increasingly sidelined on ideological grounds under what Schuurman terms 'neoliberal triumphalism', 5 and on practical grounds of policy irrelevance when critics began to conflate the cultural turn in development studies as constituting the entire scope of 'critical development'.

In its place, little has emerged in the way of novel critical scholarship from within international development studies to move us beyond what Ferguson terms 'the politics of the "anti". 6 As Ferguson points to, these politics of denunciation contribute little understanding to the contemporary practices of new actors and alliances involved in the geographical and technical areas that were once the purvey of states, NGOs and consultants acting on their behalf. International development is goal- and target-oriented: it tends to be pre-occupied with the future, and is thus largely unreflexive, ${ }^{7}$ but critical development studies need not suffer the same weaknesses. Meanwhile, most understanding of contemporary development practices remains dominated by economists who study the policies of states and international organizations aimed at promoting economic growth, and occasionally featuring poverty reduction in post-MDG times.

We recognize that considerable knowledge can be gained from parsimonious explanations of when development happens through aid, by whom, and how, ${ }^{8}$ yet there is a need to further expand the scope of aid actors to be studied and the disciplinary methods used to understand them. This, we argue, can contribute to critical development studies. This issue responds to a call for scholarship that engages global issues comparatively but with a proper respect for the differences that place makes (for the legacies of geography and history). ${ }^{9}$ Using qualitative methodologies, typically based on fieldwork and empirical data collection, the contributions provide cross-disciplinary and nuanced analyses of the practices of development relations in particular contexts. While this special issue focuses on documenting 'new' contemporary actors, the inclusion of grounded historical work is essential in order to 'provide critical responses to the historical effects of colonialism and the persistence of colonial forms of power and knowledge into the present'. ${ }^{10}$ The contributors were purposively chosen for their potential contributions to development studies that are 
based on empirical, not ontological, critique. Critical development studies can not decouple theory from policy-oriented development practice - to do so would be to neglect the moral responsibilities held by scholars from various geographical and disciplinary places who document and argue for changes in policies and politics elsewhere. $^{11}$

Important questions for critical development scholarship and engaged policy are raised by these grounded studies: Are there important common traits in these new actors and alliances? To what extent are they 'new' and what are the historical trajectories of current trends? How do these actors and alliances act as agents of development? How are new actors and alliances shaping images, communication and representations of development? What are the implications of these new actors and alliances for critical development studies?

The rest of this introduction will examine a set of key debates addressed by the contributions as well as indicating some of the answers to the questions posed above. An epilogue to this special issue by Banks and Hulme provides a complementary perspective on the articles through the lenses of poverty alleviation and inequality. Through an analysis of the relative roles of state, market and civil society in 'new' development alliances, Banks and Hulme conclude that their transformative potential is limited by their disregard of civil society.

\section{The Development Aid Debate}

In the contemporary context in which 'economic scarcity' refers not only to the 'lacking' economies in the developing world, but also to their 'donors', the place of new actors and alliances in development becomes increasingly prescient. Even development issues of unprecedented popularity for international donor funding have been hit by the global economic crisis. For example, funding for HIV/AIDS fell by 10 per cent in 2010 from the previous year, which is the first time that such funding dropped in more than a decade (between 2002-2008 spending for HIV/AIDS rose more than six fold). ${ }^{12}$ Private funding is becoming more important in development as traditional sources are under stress from the effect of a shrinking tax base due to the contemporary economic crisis. This is reflected by a historical trend of shifting 
patterns of resource transfers from North to South. Sources of development financing that are outside official development assistance are growing and diversifying, and this is shaping the funding and agenda of development.

Official development assistance (ODA) is defined by the OECD and the IMF as 'flows of official financing administered with the promotion of the economic development and welfare of developing countries as the main objective, and which are concessional in character with a grant element of at least 25 percent (using a fixed 10 per cent rate of discount). By convention, ODA flows comprise contributions of donor government agencies, at all levels, to developing countries (bilateral ODA) and to multilateral institutions. ${ }^{, 13}$ ODA is becoming less important in relative terms for both the material and the symbolic meaning of development assistance. Between the 1960s and the late 2000s, the public/private patterns of transferring resources from donor countries to development recipients have reversed to the point that, in 2007, philanthropy from all OECD donor countries amounted to $\$ 49.1$ billion, remittances to $\$ 14.6$ billion and private investment to $\$ 325.4$ billion: in sum, private flows represented 83 per cent of all flows, while public ODA was only 17 per cent. ${ }^{14}$ This reversal in the ways of engaging between North and South, from public aid to private flows, has been acclaimed for providing better 'development'. ${ }^{15}$ Yet, we know very little about the actual development impact of private flows, even less than we know about the impact of ODA, which remains inadequate. ${ }^{16}$ We do know that this material shift in how resources flow has been accompanied by a symbolic shift about the meaning of development, who should be involved and how.

The fundamental debates in development - whether they are conducted by scholars, practitioners, politicians, donor or recipient constituencies- have formed around one main question: 'does development assistance work?' Does a transfer of funding, material resources or services from donor to recipient, bring about economic growth and employment, improved governing institutions, better health, education or political participation? Tierney and colleagues review the academic debates since 1990 over aid effectiveness, and summarize them into three schools of thought: 'more aid,' 'problem aid' and 'conditional aid'. ${ }^{17}$ Given the comprehensiveness of the recent review, we will not repeat the academic grounding for these positions here. ${ }^{18}$ However, it is important to keep in mind that academically significant empirical 
evidence has been published to support contradictory positions. And as summarized by Tierney et al., 'the roughly one million official development projects and activities over 66 years have brought little certainty about the scope, purposes, or effects of development finance. Not for the public whose tax dollars fund aid; not for the foreign aid scholars; not for development practitioners; and certainly not for the recipients of foreign aid'. ${ }^{19}$

The polarization in the more 'popular' debate on international aid ${ }^{20}$ has played along two main parallel axes: (1) aid is bad because there is not enough of it - from this perspective that proposes more aid, a grand plan, or a big push, is needed to get the poorest countries out of their predicament (especially in Africa) and; (2) aid is bad because there is too much of it going to the wrong places - this perspective argues that aid is wasted due to bad governance in recipient countries (especially in Africa) and proposes solutions ranging from less or even no aid to promoting more targeted and efficient aid. In practice, supporters of the big push theory (notably, Jeffrey Sachs) tend to undermine the effect of corruption on aid delivery and growth. Conversely, supporters of smaller, more targeted aid (notably, William Easterly, Robert Calderisi and Dambisa Moyo), tend to place more importance on corruption and argue that less aid, not more, is needed, because more money will inevitably lead to more corruption.

While from a scholarly perspective, these debates appear fatally simplistic, engaging in a 'chicken and egg'-type debate over whether increasing aid, or decreasing corruption in fact comes first, they are important for understanding the power of engaging new actors in development. The form of these debates in which famous authors target audiences of 'non-experts' is significant, but perhaps more significant is the skillful management of affect, of individual desire to 'do good,' in these texts. Thus, statements that are both simplified and generalized to the point of being indisputable (one can not dispute with arguments that are not based on evidential claims) form the engagement between a caring public and their international development possibilities. Yet, what really counts in these debates in relation to the focus of this special issue is that both camps generate ideological support for the engagement of business as development agent (in ways that goes beyond the generation of economic growth and employment), of consumers as donors, of 
celebrities as key communicators and mediators, and of private philanthropic foundations as rising agenda setters in sectors like health and agriculture in developing countries. The Director of the Hudson Institute argues that there is a dialectical relationship between new actors and alliances and traditional aid: 'Official aid is a minority shareholder in the growth and development of poor countries. As a result, government aid agencies are beginning to change their business models to leverage official aid with activities launched and run by businesses, foundations, charities, religious groups, universities, and even remittances being sent back to hometowns for community projects'. ${ }^{21}$

\section{A New Role for Business in Development}

Both the 'aid is bad because it is too little' and the 'aid is bad because it is too much' camps seem to agree that government interventions and 'traditional' aid are not likely to hold the solution to either problem. However, business is held in favourable view by all sides in this debate. We briefly examine three linkages between business and development in this section: (1) development-oriented activities that fall under the broad agenda of Corporate Social Responsibility (CSR); (2) Cause-Related Marketing (CRM); and (3) Bottom of the Pyramid (BOP) business approaches to development.

Corporate Social Responsibility has operated under a number of names and definitions through its rapid practical proliferation and conceptual development. ${ }^{22}$ Although the issue of the social responsibility of business can be found in writings that go back centuries, examination of business as a social actor has expanded considerably in the last half century or so. ${ }^{23}$ The European Commission defines CSR as 'a concept whereby companies integrate social and environmental concerns in their business operations and in their interaction with their stakeholders on a voluntary basis'. ${ }^{24}$ But other definitions of CSR expand responsibility to cover society as a whole, not just the company's immediate stakeholders. Alongside a large literature in business studies, a thriving reflective literature on the role of CSR in international development has also emerged. Much of it concurs that not enough is known on the actual impact of CSR activities in developing countries ${ }^{25}$ or about the complicated relationships linking CSR and desirable developmental outcomes, particularly in 
Africa ${ }^{26}$ It also argues that CSR often actually distracts attention from the root causes of poverty and environmental destruction. ${ }^{27}$ Related to CSR, an equally large literature has examined whether sustainability certifications promote positive outcomes for beneficiaries in developing countries, finding mixed results. ${ }^{28}$ But for all their limitations, at least CSR and sustainability certifications seek - to different degrees - to improve production and trade conditions for Southern producers and other actors that bring a product to the (Northern) market.

In contrast, the link between social and environmental conditions of production and beneficiaries is dissolved in Cause-Related Marketing (CRM) initiatives. In CRM, the marketing of a brand, company, product or service is tied directly to a cause (including international development causes), with a proportion of the sales going to support the cause. These 'transactional programs' are classic exchange-based donations, where a corporation agrees to give a specified share of the proceeds for every unit sold. ${ }^{29} \mathrm{CRM}$ can be used for meeting overarching business goals (including the drive for profits), and strengthening brand reputation and employee loyalty, aiding recruitment and retention. ${ }^{30} \mathrm{CRM}$ also shifts consumer attitudes, as companies become represented as 'yearning to connect to people and things that will give meaning to their lives'. ${ }^{31}$ In the process, business improves brand reputation and sales, without needing to reconsider any of its actual operations and practices. ${ }^{32}$

The most orthodox interpretation of the 'business can solve development problems' argument comes from 'Bottom of the Pyramid (BOP)' approaches, articulated by Prahalad. ${ }^{33}$ In BOP approaches, the key to helping the poor to help themselves is to convince business that BOP markets are important. Business is seen as the key solution in addressing poverty because it can 'create opportunities for the poor by offering them choices and encouraging self-esteem'. ${ }^{34}$ Prahalad criticises the traditional approach used to create the capacity for poor people to become consumers - providing products or services for free. He seeks to encourage consumption in BOP markets by making unit packages small and more affordable (due to the poor's unpredictable income flows), and by using new purchase schemes - such as providing credit to consumers in new ways. Not only is there money at the BOP, and profitmaking potential, but these markets are also brand conscious. Similarly to CRM, BOP approaches do not address the conditions of inequality and or poverty that are 
responsible for their inability to consume in the first place. The difference is that in BOP approaches, the focus is on consumers in the South; in CRM approaches, the focus is on consumers in the North. In both, the production and trade relations that are embedded in consumer products disappear.

\section{Contribution of the articles in this special issue}

Two articles in this collection specifically focus on the changing role of business in development. Blowfield and Dolan's article provides a comprehensive discussion of how the conceptualization of business in development has changed over time and where it stands now as poverty has been redefined as a condition amenable to market intervention. They show that business has long been recognized as a key actor in economic development through its traditional roles in investment, production, trade and retail. These activities contribute to job creation, the supply of goods and services, and the funding of social services though taxation. In this classic role as 'development tool', business is active but not responsible for development outcomes. Blowfield and Dolan, however, argue that business is increasingly showing interest not only in developing countries as sites of investment, production, trade or distribution, but in the development of these countries as well. This is often the result of self-interest, but one that can involve 'mutual interest between companies and the poor or otherwise marginalized'. ${ }^{35}$ They examine these processes by drawing from a number of studies of what they call 'bottom billion capitalism' initiatives, including that of Fairtrade in tea and flowers in Kenya, and of BoP initiatives such as the CARE Bangladesh Rural Sales Programme (RSP) and Avon South Africa.

'Bottom Billion Capitalism' according to Blowfield and Dolan is a 'model of inclusive business that recasts poverty as a site of opportunity for both business and the poor', underpinned by the principle that markets can work for the poor. The term is the merging of two other terms coined by Collier ${ }^{36}$ - focusing on the population of poor 'bottom billion' countries that are stuck in poverty traps - and by Prahalad ${ }^{37}$ denoting the 'Bottom of the Pyramid' four billion people earning less than two dollars a day. Blowfield and Dolan highlight that business is involved in a wide range of 'bottom billion capitalism' initiatives not only in terms of engaging with the bottom billions but also in casting them as 'clients', 'partners' and 'entrepreneurs', shifting 
the discourse of the poor from beneficiaries of aid to active market actors. ${ }^{38}$ They conclude critically that to be true 'development agents', rather than simply development actors or tools, business also needs to give primacy to the benefits for the poor and marginalized and to strive to address poverty and marginalization. Thus, business would be required to become accountable to developing country citizens in ways that it currently is not.

McGoey's article shows that business is affecting development-related processes and institutions not only directly, but also by exporting its management models to the nonprofit and philanthropic sectors. She draws parallels between the contemporary philanthrocapitalists such as Bill Gates and early $20^{\text {th }}$-century philanthropists such as Rockefeller and Ford to suggest that the contemporary phase 'is simultaneously far less novel and more novel than proponents suggest'. She points out that shaping philanthropic organizations to operate like business was actually John D. Rockefeller's original idea - what is new about is 'the unprecedented scale of philanthropic spending'.

McGoey's analysis draws on three case studies based on a wealth of primary interview material: (1) governmental grants to profitable companies such as Vodafone (for the establishment of M-Pesa, a system first developed in Kenya to allow people to pay bills through text messaging); (2) increased governmental support for 'impact investing' (investment in projects providing environmental and social benefits with the expectation of 'market-rate' financial returns); and (3) the relative roles of the Gates Foundation and of governments in promoting and financing the first AdvancedMarket Commitment (AMC) to encourage the development of drugs and vaccines for underfunded diseases.

Using theory from the economists Lazonick and Mazzucato on the 'risk-reward nexus,' McGoey shows that just as government interventions were key to the development of global markets in the $19^{\text {th }}$ and $20^{\text {th }}$ centuries, state support remains essential to the rise of contemporary philanthrocapitalists. 'Governments are, somewhat ironically, instrumental to the success of philanthropic movements strengthened by proclaiming the ineptitude and waning influence of government policies .... [they] are extending themselves in new directions in a semblance of 
surrendering control to private entities that are, in many ways, less entrepreneurial than governments themselves'. She concludes that philanthrocapitalists have helped to perpetuate the belief that the private sector is filling public sector gaps in development financing, while in reality it is often governments that subsidize the philanthrocapitalists.

\section{Consumers and Celebrities as Development Actors}

Recasting the role of business in development is accompanied by the increasing engagement of consumers and celebrities as development actors. 'Ethical consumers are those whose decisions about what to consume (the "consumption" part) are shaped by their assessment of the moral nature of that context (the "ethical" part)". 39 There has been increasing interest in, and debate on, various forms of ethical and political consumption over the past two decades. A rich literature has fine-tuned the links between the ethics and the politics of consumption, ${ }^{40}$ examined the ethics of 'everyday consumption', ${ }^{41}$ or argued that ethical consumption is a dangerous myth. ${ }^{42}$ One of the important aspects emerging from this literature is the fact that the possibility of 'consuming ethically' is often based on the consumption of branded products, despite the 'No Logo' battle cry of the anti-globalization movement. In other words, it is brands' vulnerability to ethical concerns that opens up space for consumer action. But because branded companies seek to minimize such vulnerability, they are also developing initiatives (such as cause-related marketing) that detach ethical concerns from the products themselves, and relocate them instead to the ethics of supporting a development cause.

A culture of consumption promotes freedom of choice and consumer sovereignty, and strives to meet needs that are in principle unlimited and insatiable. ${ }^{43}$ The consumption of signs and experiences can be the vehicle for the mobilization of 'meaning', belonging to a 'community', political action and development intervention. Citizenconsumers are increasingly seen as exercising their rights to demand developmental outcomes via individual acts of 'consumption for a cause'. But while consumer agency may take the form of collective action through campaigns and consumer organizations' pressure, the focus of these campaigns is often on the individual act of consumption of branded products. As the value of goods depends increasingly more 
on their 'sign' than on their functional or economic value, advertising, marketing and branding become central functions on their own, not subordinate to production. ${ }^{44}$ In many cases, this kind of consumption is mobilized by celebrities through the management of affect. Consumption then can delineate values and form a partial basis for creating a community that 'cares' for development.

The state of the art understanding of ethical and political consumption rests on the core belief that reconnecting the sites of consumption with those of production will enable a fairer distribution of value along the chains, potentially driven by 'fair trade' and 'ethical consumption' purchases. But while this focus on products must not be neglected, it should be accompanied by an understanding of the causes (including development) that are increasingly 'sold' together with the products, and the celebrities that translate and embody an ethical leadership role in the management of consumers' desire to do good while shopping well.

From the 'movie star on the famine stage ${ }^{, 45}$ to the 'AIDS heroes' of China, ${ }^{46}$ the past decade has seen a proliferation of celebrities appearing in productions of transnational caring. ${ }^{47}$ As celebrities become more relevant, other forms of expertise have followed along in the celebrity modality, and public figures, academics and business leaders become celebritised as well. Celebrities have become the faces of doing good, of credibility, and of believability. For example, Bono is popular as a rock star and his commitment to development advocacy over time earned him legitimacy as an expert. ${ }^{48}$ This distinguishes some celebrities as particularly effective in cause work from other stars who simply engage in 'do gooding'. ${ }^{49}$ Aid celebrities have thus become trusted advisors on issues of health, poverty, the environment or climate change in ways that extend beyond the actual scope of their research or practitioner experience, and their presence is invoked to stand in for important beliefs and social values. ${ }^{50}$ In other words, celebrities have become a way of mediating between proximity and distance in the global as well as the specific context.

\section{Contribution of the articles in this special issue}

Three articles in this special issue examine the role of consumers and/or of celebrities in development. Kothari's article shows that linking Third World producers and 
Western consumers through public campaigns, charity advertising and media promotion is deeply rooted in the history of Empire. Through her analysis of the (British) Empire Marketing Board poster campaign of 1926-1933, she argues that popular representations of the 'exotic other' sought to re-order relations between producers and consumers in ways that are not too dissimilar from contemporary campaigns. ${ }^{51}$ Kothari shows that it is important to reflect on the historical legacy of the current wave of 'ethical consumption' but without falling into a historically deterministic trap. What is more important is that we should pay specific attention to how the instrumental use of images and representations in these campaigns actually 'influence development policies, discourses and practices'. Kothari shows, literally, through the images of the Empire Marketing Board, how caring was never considered as a relation between equals. Development is sold as yet another product quality trait and contemporary initiatives that use products to link domestic and overseas histories draw on deep imperial roots.

Ponte and Richey's article covers the role of both consumers and celebrities in development, and their new alliance. They formalize a conceptual model for what they have termed 'Brand Aid', the intersection of international development causes, branded products and celebrities - placing it in the context of an institutional framework. Ponte and Richey use this model as guide to conduct a systematic empirical analysis of contemporary Brand Aid initiatives, including three in-depth case studies of General Mills' 'Win One Give One' campaign, TOMS shoes and Product (RED). They highlight how in Brand Aid initiatives, celebritized multi-media imaginaries of development are used to sell products to Northern consumers. Development outcomes themselves become so imbued with symbolic and 'ethical' value that they now are used to market consumer goods to Northern buyers, often with celebrities being part of creating 'caring brands' that sell development. Commodities are then sold as the means for achieving development for recipients and good feelings for consumers simultaneously. In the process, 'development' becomes ontologically ingrained as 'having the right things.' In Brand Aid initiatives, consumers can save distant others who have no connection with the product on sale. Instead of striving to improve production and trade conditions (as in fair trade or other sustainability initiatives), Brand Aid engages the work of a 'story factory', often generated with or through celebrities, producing emotional 'truths' about 
development and consumer engagement that make development appear simplified and manageable.

Brockington's article argues that our understanding of celebrity and development still lacks an account of how the celebrity industry and the development sector have become intertwined, and a better understanding of the political economy of these relationships. Brockington argues that celebrity in development is important not only because it mediates between Northern consumers and the receivers of 'help', but also because it facilitates access to elites. On the basis of material drawn from over a hundred interviews with employees of different NGOs, journalists and agents, managers and public relations staff (mostly in the US and UK), and from an analysis of articles in the major UK newspapers, Brockington chronicles in detail the emergence of a celebrity-charity-corporate complex as a site of negotiation, clash and overlap of interests, and the emergence of new professional figures managing the celebrity-charity interface. He shows that relations between the development sector and celebrity industries have become more organized and systematic in the last decade, and that, as a consequence, some development NGOs now have dedicated staff that is deeply engaged with agents, publicists, managers and celebrities to build effective relationships. Finally, he shows that the celebrity-charity-corporate complex is also attractive to corporate sponsors because of the valuable publicity it can facilitate, and because of 'the personal pleasure the company of the famous affords'. Brockington concludes that celebrities have become an important set of development actors, and that their presence and influence needs to be better understood by development studies scholars in future work.

\section{State Actors, Elites and Transnational Networks}

The role of the state, while pushed out of fashion in development theory by 'neoliberal triumphalism', ${ }^{52}$ is never absent from understandings of what development might mean in practice and what actors and alliances are necessary to drive it. Thus, development does not emerge spontaneously from the interplay of market forces, but rather requires concerted state interventions. Even in contexts of increasing transnationalism, states are necessary to ensure macroeconomic stability and provide infrastructure, utilities, and selective industrial policies. In this collection, Whitfield 
and Buur argue that 'few non-traditional export success stories from anywhere around the world occurred without the help of industrial policies of some sort, such as assisting the absorption and learning of new technologies, export subsidies, and preferential tariff arrangements' ${ }^{53}$ There is increasing agreement on the necessity of industrial policy and the importance of the state, although the details of how this should take place in varying contexts continue to be debated. ${ }^{54}$ At the center of many debates on state actors and elites in development, we find the resurgence of African 'exceptionalism'. There is a highly skeptical literature on the capacity of African states to effectively engage as development actors. ${ }^{55}$ Specifically, it is argued that African states lack capacity due to the prevalence of neo-patrimonial politics and bad political leadership. Within African states, ruling elites have often been seen as sources of underdevelopment because they exploit public resources for personal gain and narrow elite or ethnic interests. ${ }^{56}$ Structural adjustment programs sought to undo these alliances, by taking away many of the tools of the state to support the emergence, consolidation or expansion of a group of domestic capitalists. Yet, in the era of privatized international development efforts, these very elites, their relations to industry and to the state, are being reconsidered.

The power politics that play into elite alliances and state capacity for development are not limited to those which are geographically-bound within developing countries. Transnational networks are increasingly studied for the ways that they operate a 'boomerang' set of linkages that are initiated by domestic organizations that 'bypass their state and directly search out international allies to try to bring pressure on their states from outside'. ${ }^{57}$ Keck and Sikkink ${ }^{58}$ argue that the linkages between international allies and the victim or target group are mutually beneficial, providing access, leverage and money in exchange for credibility of benefactors as struggling with, not only for, their Southern partners. However, such 'boomerang politics' for development involve extensive complications around resource control and the management of the representation of the development 'problem' termed 'information politics.' As these transnational actors gain in legitimacy on the basis of their perceived access to accurate but often-overlooked information, they enjoy more public trust than states, businesses and the media. ${ }^{59}$

\section{Contribution of the articles in this special issue}


In addition to McGoey's intervention already summarized above, three articles in this collection examine state actors, elites and transnational networks and their new, returning and/or reconfigured role in development. Whitfield and Buur's article examines the resurgence of an alliance that has always been central to the process of economic development - that between ruling elites and domestic productive capitalists. These alliances are now experiencing heightened attention from scholars and policy makers with the current revival of debates around industrial policy in developing countries. Whitfield and Buur draw from in-depth and fieldwork-based case studies of the evolution of two successful productive sectors in Africa (sugar in Mozambique and cocoa in Ghana), carried out by the authors as part of the larger research programme 'Elites, Production and Poverty'. They highlight the conditions under which alliances between ruling elites and domestic productive capitalists occur, their specific characteristics, and outcomes. With careful attention to historical and contextual specificity, Whitfield and Buur show that close relations between ruling elites and capitalists are not necessarily 'crony' or unproductive. Under certain conditions, they can lead to positive development outcomes. This happens when the following conditions are met: there are mutual interests between ruling elites and productive capitalists; factional demands within the ruling coalition can be managed in order to create 'pockets of efficiency' in the bureaucracy; and state bureaucrats engage in institutionalized relations with industry actors under a framework providing clear incentives for increasing productivity or expanding an industry. Whitfield and Buur, however, also provide a cautionary note - alliances can change with transformations in the configuration of political power or the power of capitalists, and thus their developmental outcomes are far from assured in the long term.

Kragelund's article highlights how non-traditional state actors (emerging donor countries such as China, India and Brazil) contribute to creating 'developmental space' in policy-making in Africa. He points out that while some of these actors have been active in Africa for decades (China in particular), their renewed involvement and the specific modality of this involvement signals the weakening of an old alliance (between African states and DAC donors) and the strengthening of a new one. Kragelund applies Harrison's concept of the 'sovereign frontier' ${ }^{60}$ to move us 'beyond the traditional discussion of whether or not African states are indeed sovereign ... to a 
discussion of how a variety of domestic and international actors interact to shape the (changing) development space'. In his fieldwork-based case study in Zambia, Kragelund examines the role of China, India and Brazil in financing development activities and in promoting alternative development models. He argues that it is not the size of financial flows from these emerging donors that counts - these are still small compared to DAC countries. What is most important is that new donors are providing alternative models of development that combine purposive state intervention with market-based economic growth and integration into world markets, while maintaining a high degree of national control. He shows that the Zambian state is taking its first steps in strengthening its 'sovereign frontier' of development, but also that the extent of this movement is still small and development outcomes remain far from assured.

Budabin's article examines the alliance between diaspora groups and transnational advocacy networks. Through her analysis of primary data documenting the relations between the Darfuri diaspora in the US and the Save Darfur Coalition (an advocacy NGO embedded in a transnational network), Budabin shows that the uneven constitution of alliances between unequally-resourced actors limits the abilities of groups like the Darfuri diaspora to act as development agents. The article emphasizes that looking simultaneously at the home and host country contexts is key in understanding the strength and viability of transnational alliances. While diaspora groups can provide the emotional 'pull' in the host country for improved visibility, lack of strong ties in the home country, political cleavages, and the short-termism of advocacy networks can limit the longer-term development potential of these alliances and lead to an exclusive focus on humanitarian aid. Still, transnational linkages remain important for diasporas because of their need to align with better-resourced groups that provide necessary financing, communications skills and political access in the host country. For the NGOs, engaging in transnational advocacy networks with diaspora groups provides them with an advantage in the 'information politics' of negotiating between legitimate representation of 'others' and policy 'asks' on their behalf.

\section{Conclusion}


The contributions to this special issue analyze the rise of new actors, the transformation of old actors, and the configuration of new alliances in development. In previous sections, we have highlighted the contribution these articles offer in relation to understanding: the new role of business in development; the involvement of consumers and celebrities as development actors; and the complex interactions between state actors, elites and transnational networks. In this last section, we provide some answers to the questions raised in the introductory section and suggest future directions for critical development studies.

Are there important common traits in these new actors and alliances? The articles in this collection demonstrate two main commonalities: hybrid transnationalism and diffuse notions of development responsibility. First, hybrid transnationalism is seen across the studies as resulting from the geopolitical situatedness of the resources generated to support the new actors and alliances in development: funds from global philanthropists, advocacy networks, and development-minded consumers are raised to support causes that are sold as being 'above politics'. This hybrid transnationalism means that development has not become firmly cosmopolitan in the ways that would oblige equivalences between distant strangers and close kin and would thus also necessitate struggles against global inequality, in the midst of all the 'helping.' Neither is development geopolitically configured along the traditional lines of DAC donors, bilaterals and multilaterals, or NGOs and states. Many of the new actors and alliances here fall clearly in between, they are neither local nor global — but instead, hybrid transnationals.

Second, the new actors and alliances explored in these contributions suggest that most are active as development tools - active, but not responsible for development - and that a diffuse notion of responsibility characterizes the relationships between them. As illustrated by Blowfield and Dolan in this issue, ${ }^{61}$ the new actors and alliances are 'no more responsible for development outcomes than a hammer is responsible for the carpenter's thumb'. Yet, the articles in this special issue suggest that a clearer understanding of development responsibility could be better achieved through an empirical analysis of the mechanisms that are producing these new alliances between actors and between processes of development and their supposed beneficiaries. 
To what extent are these actors and alliances 'new' and what are the historical trajectories of current trends? As might be anticipated, nothing we see in contemporary development practices is without specific or combined historical precedent. Most explicitly, Kothari shows how the visualizations of self and state created possibilities of empire in ways analogous to how development relations are depicted as a shared struggle for good commodity provision and consumption. ${ }^{62}$ Whitfield and Buur demonstrate how ruling elites and domestic productive capitalist relations seen in Mozambique and Ghana have historical precedents in the sugar plantations and small-holder cocoa farms, and that these continue to present challenges for contemporary development. ${ }^{63}$ Alliances between new aid actors (China, India and Brazil) and the Zambian state are formed upon the fraught history of the country's domination by its traditional donors and lenders as shown by Kragelund. ${ }^{64}$ And while the scale of contemporary philanthrocapitalism may appear extreme, McGoey traces this to the $19^{\text {th }}$ century development of international markets, with the state remaining central, even though concealed by the relations of 'new' philanthropy. ${ }^{65}$ In sum, these actors and alliances are not new per se, but they are newly being studied by development studies scholars as engaging in practices that are now coming to be understood as an important part of the rubric of what constitutes 'development.'

How do these actors and alliances act as agents of development? In the positioning of agency in development, we see a new twist in which intentionality or motivation is less important than engagement of one's own (individual or corporate) resources in the risky activity of development. For example, in Blowfield and Dolan's definition of what makes a development agent - willingness to deploy one's assets for development activity, not whether or not there is a profit motive - should be central. In Ponte and Richey's examination of Brand Aid, development's value as a product feature is not lessened by consumer commitment toward conspicuous consumption or by businesses capitalization on the affective need to 'help.' In Brockington's analysis, the investment of celebrities' time and publicity capital suggest that they too may be legitimate development agents, and that development causes are also risky endeavors for the profile of A-list celebrity. Bill Gates (in McGoey's contribution), 'nontraditional state actors' (in Kragelund's), and the Darfuri Diaspora (in Budabin's) are all investing their own assets for developmental activity, and thus meet one of the 
criteria for constituting them as development agents. However, Blowfield and Dolan's (in this collection) other criteria for defining agency in development-propoor primacy and accountability — are much more difficult to meet for many of the development actors examined in this collection.

How are new actors and alliances shaping images, communications and representations of development? The power of storytelling, including visual representation, has been largely neglected by development scholars. ${ }^{66}$ Yet, the power of international development representations is not simply a material power that stems from the way that alliances engage business, consumers and other development actors. Their impact is also based in images - pictures of the world. Northern shoppers are animated by a confident aid celebrity Bono who speaks from American television screens claiming: 'We can be the generation that ends extreme poverty. This is our moment to show what we're about'. International development's expansion to include new actors among the so-called 'generation-net' calls for critical consideration of communication, including those from the perspective of those affected by it. ${ }^{67}$ Drawing on the emotional in political life and on the affective politics of development, some new actors like celebrities shape the form of representation of international development and constructions of identity that are always co-constituted through imaginaries of 'us' and 'them, ${ }^{68}$ - often with imperial, ${ }^{69}$ racist $^{70}$ and religious legacies. $^{71}$

Several contributions in this collection speak to these issues. Budabin lends weight to the argument that transnational networks, with their presumptions of legitimacy, ${ }^{72}$ rely to a large extent on their ability to furnish compelling stories. ${ }^{73}$ As also argued by Keck and Sikkink, the information flows from and around these alliances 'provide not only facts, but testimony - stories told by people whose lives have been affected'. ${ }^{74}$ Brockington, however, suggests that celebrity testimonies may be even more important than those of the affected: 'When public figures handle interviews they can speak with more conviction and ease, they are able to tell stories of people they met, adding much more colour' ${ }^{75}$

Kothari's and Ponte and Richey's contributions in this collection support the argument that "suffering strangers" ${ }^{, 76}$ and "“iconic figures" of misfortune" 
produced, reproduced, formed and transformed according to the stories that need to be told to garner public support. Thus, controversially, it appears that as international development becomes more democratic, including more non-expert voices, it also becomes increasingly reliant on the silencing of complexity, conflict, and on the ground realities of development interventions. Through the creation of representational consensus, with the same stories and pictures circulated in various forms of expert and popular media, notions of under-development become popularized via 'reductive repetition" 78 and diverse subjectivies are placed together into the 'suffering slot' that has replaced the 'savage' as the privileged object of cross-cultural attention. ${ }^{79}$ Ponte and Richey push this argument even further, arguing that Brand Aid initiatives not only use imaginaries of development to sell products to Northern consumers, but also engage in the work of a 'story factory' - producing truths about international development and consumer engagement that make development appear simplified, manageable and marketable. ${ }^{80}$ As Budabin (this issue) explains in the policy space possible for some diaspora groups and not others, 'not everyone is a good speaker', and as Ponte and Richey illustrate, those whose stories do not compel, do not sell. This has relevant implications for both the performances and the politics of development.

\section{What are the implications of these new actors and alliances for critical development} studies? The articles in this special issue indicate important directions for research in critical development studies in staking a middle ground between post-development/ anti-development culturalism and materialist political economy critiques of development as exploitation. First, they suggest that critical research does not have to remain disengaged from development practices - as much of the earlier postdevelopment or anti-development theory had suggested. Critiquing practices and their justificatory premises through Corbridge's provision of Weber's 'inconvenient facts ${ }^{81}$ can provide a better understanding of the implications of the mechanisms through which development works. These practices may well oppress people, but they may also provide the master's tools necessary for taking down his house (to reverse paraphrase Audre Lorde). ${ }^{82}$ Second, these contributions point to new areas for studying international development in its hybrid transnational nature as fruitful - in addition to the ongoing relationships between international organizations, states and NGOs. Research should look outside the usual scope of development confined by 
ODA to find out what practices are taking place, what they might mean, and how they might intersect with the practices we conventionally study as international development. Third, the articles in this collection suggest that development studies could be better understood as part of the intellectual scope of global studies: because the geographical scope of development actors and its recipients is increasingly lessconfined to 'developing countries'; and because hybrid transnational actors and alliances cross boundaries between state, international organizations and NGOs. ${ }^{83}$ This is not a call for less attention to empirical data collection, including fieldwork in developing country sites, but instead a reading of these new actors and alliances through the lens of the global. Fourth, critical development studies must be willing to engage both the material and the representational sides of development interventions. Questions raised around representations of development relate quite directly to the political economy of the 'asks' that form policy and practices in these new alliances and roles of new actors. Who can legitimately ask for what for whom and from whom? Critical development scholars should bring empirical evidence to bear on political, not merely technical, debates around development, new actors and alliances and changing configurations of North-South relations. A political economy of interests, not an ideological blindness built on the assumptions of altruism, would guide better understandings of development actors and alliances. At the same time, the symbolic value of the performance of altruism must be taken into the development calculus.

\section{Acknowledgements}

The authors would like to thank the participants of the EADI/DSA conference panel on "New actors and alliances in development", University of York (20 September 2011) and Jan Nederveen Pieterse for feedback on this introduction.

\section{Endnotes}

\footnotetext{
${ }^{1}$ Corbridge, "The (im)possibility of development studies", p. 202.

${ }^{2}$ Woolcock, Szreter and Rao, "How and Why Does History Matter".

${ }^{3}$ See Crush, Power of Development; Escobar, Encountering Development; Nederveen Pieterse, Development theory; Sachs, The Development Dictionary; and Sylvester, "Development and postcolonial studies".

${ }^{4}$ Ferguson, The Anti-Politics Machine, p. xv.

${ }^{5}$ Schuurman," Critical development theory".

${ }^{6}$ Ferguson, Expectations of Modernity.

${ }^{7}$ Kothari, "Critiquing 'race' and racism”, p. 67.
} 
${ }^{8}$ See, inter alia, Tierney et al., "More dollars than sense".

${ }^{9}$ See Corbridge, "The (im)possibility".

${ }^{10}$ Kothari, "Commentary", p. 69.

${ }^{11}$ See Corbridge, "The (im)possibility".

${ }^{12}$ Investing Wisely in HIV/AIDS. The Lancet Infectious Diseases, Volume 12, Issue 1, Page 1, January 2012. http://www.thelancet.com/journals/laninf/article/PIIS1473-3099(11)70357-

7/fulltext?rss=yes

${ }^{13} \mathrm{http} / / /$ stats.oecd.org/glossary/detail.asp?ID=6043 IMF, 2003, External Debt Statistics: Guide for Compilers and Users - Appendix III, Glossary, IMF, Washington DC.

${ }^{14}$ Adelman, "Global philanthropy and remittances", p. 27.

15 Ibid.

${ }^{16}$ Tierney et al., "More dollars than sense".

${ }^{17}$ Ibid., pp. 1893-4.

${ }^{18}$ For detailed literature reviews see also Hansen and Tarp, "Aid effectiveness disputed"; Tarp,

Foreign Aid and Development; Riddell, Does foreign aid really work?

${ }^{19}$ Tierney et al., "More dollars than sense", p. 1891

${ }^{20}$ See, inter alia, Sachs, The End of Poverty; Calderisi, The Trouble with Africa; Easterly, The White Man's Burden; Moyo, Dead Aid.

${ }^{21}$ Adelman, "Global philanthropy", p. 24

${ }^{22}$ Wartick and Cochran, "The evolution of the corporate social performance model".

${ }^{23}$ Carroll, "Corporate Social Responsibility".

${ }^{24}$ See http://ec.europa.eu/

${ }^{25}$ Blowfield, "Reasons to be cheerful?"; Newell and Frynas, "Beyond CSR?"

${ }^{26}$ Idemudia, "Corporate social responsibility and developing countries".

${ }^{27}$ Newell, "CSR and the limits of capital".

${ }_{28}$ Among many others, see Gibbon et al., Global Agro-food Trade and Standards.

${ }^{29}$ Berglind and Nakata, "Cause-related marketing".

${ }^{30}$ King, Pink Ribbons, Inc., p. 9

${ }^{31}$ Ibid., p. 11.

${ }^{32}$ Richey \& Ponte, Brand Aid.

${ }^{33}$ Prahalad, The Fortune at the Bottom of the Pyramid.

${ }^{34}$ Ibid., p. 5.

${ }^{35}$ Ibid.

${ }^{36}$ Collier, The Bottom Billion.

${ }^{37}$ Prahalad, The Fortune.

${ }^{38}$ Ponte and Richey, "Buying into Development", show that while in BoP initiatives the poor are being cast as active market actors, in Brand Aid 'deserving others' are used as marketing tools to sell products to Western consumers. The 'poor', 'African', 'women and children' in these initiatives are passive receivers, who have no agency.

${ }^{39}$ Carrier, "Introduction", p. 1.

${ }^{40}$ Clarke et al., "Globalising the consumer"; Clarke, "From ethical consumerism to political consumption"; Barnett et al., Globalizing Responsibility; Carrier and Luetchford, Ethical Consumption.

${ }^{41}$ Miller, The Dialectics of Shopping; Barnett et al., "Consuming ethics".

${ }^{42}$ Devinney et al., The Myth of the Ethical Consumer.

${ }^{43}$ Slater, Consumer Culture and Modernity.

${ }^{44}$ Bandelj and Wherry, The Cultural Wealth of Nations.

${ }^{45}$ De Waal, "The humanitarian carnival".

${ }^{46}$ Hood, "Celebrity philanthropy".

${ }^{47}$ See also Brockington, Celebrity and the Environment.

${ }^{48}$ Cooper, "Beyond one image fits all".

${ }^{49}$ See Boykoff and Goodman, "Conspicuous redemption"; Goodman and Barnes, "Star/poverty space"; Littler, "I feel your pain"”.

${ }^{50}$ See Richey and Ponte, Brand Aid.

${ }^{51}$ See also Trentmann, "An introduction".

${ }^{52}$ Schuurman, "Critical development theory".

${ }^{53}$ See also Rodrik, One economics, many recipes.

${ }^{54}$ See Cimoli et al., Industrial Policy and Development; Lin, New Structural Economics.

${ }^{55}$ Noman and Stiglitz, Good Growth and Governance in Africa. 
${ }^{56}$ see, for example Mills, Why Africa Is Poor; Sandbrook and Barker, The Politics of Africa's Economic Stagnation; van de Walle, African Economies and the Politics of Permanent Crisis.

${ }^{57}$ Keck and Sikkink, Activists Beyond Borders, p. 12.

${ }^{58}$ Ibid.

${ }^{59}$ Wade, "Accountability gone wrong”, p. 26.

${ }^{60}$ Harrison, "Debt, Development and Intervention in Africa".

${ }^{61}$ Blowfield and Dolan. "Business as a development agent".

${ }^{62}$ Khotari, "Trade, consumption and development alliances".

${ }^{63}$ Whitfield and Buur, "The politics of industrial policy".

${ }^{64}$ Kragelund, "'Donors go back home'.

${ }^{65}$ McGoey, "The Philanthropic State".

${ }^{66}$ For notable exceptions, see Smith and Yanacopulos, "Special Issue: The Public Faces of Development"; and Nair, "Governance, representation and international aid".

${ }^{67}$ See Alhassan and Chakravartty, "Postcolonial Media Policy" for a critical review.

${ }^{68}$ See Hall, "The West and the rest"; Crush, Power of Development.

${ }^{69}$ See Kapoor, Celebrity Humanitarianism; Harrison, "Campaign Africa”.

${ }^{70}$ See Nederveen Pieterse, White on Black; Kothari, "Commentary".

${ }^{71}$ Richey and Ponte, Brand Aid.

${ }^{72}$ Wade, "Accountability".

${ }^{73}$ Budabin, "Diasporas"

${ }^{74}$ Keck and Sikkink, Activists Beyond Borders, p. 19.

${ }^{75}$ Brockington, "The production and construction of celebrity advocacy".

${ }^{76}$ Butt, "The suffering stranger".

${ }^{77}$ Fassin, When Bodies Remember, p. 22.

${ }^{78}$ Andreasson, "Orientalism and African development studies".

${ }^{79}$ Robbins, "Beyond the Suffering Subject."

${ }^{80}$ Ponte and Richey, "Buying “.

${ }^{81}$ Corbridge, "The (im)possibility", p. 201.

${ }^{82}$ Lorde's (Sister Outsider, p. 10) famous essay, “The Master's Tools Will Never Dismantle the Master's House" actually suggests that fundamental critique can not be based upon existing categories, such as 'woman'; however, our argument is based on the conduct of a practice-based critique (see for example, Adler and Pouliot, International Practices).

${ }^{83}$ This collection offers a more practice-based interrogation of development than Nederveen Pieterse's (Globalization and Culture) notions of hybridization as the 'rhizome of culture' drawing a middle ground in descriptions of the effects of cultural globalization on developing countries.

\section{Bibliography}

Adelman, C. "Global philanthropy and remittances: Reinventing foreign aid". The Brown Journal of World Affairs 15 no 2 (2009): 23-33.

Adler, E. and V. Pouliot, eds. International Practices, Cambridge: Cambridge University Press, 2011.

Alhassan, A. and P. Chakravartty. "Postcolonial Media Policy Under the Long Shadow of Empire". In The Handbook of Global Media and Communication Policy, First Edition, edited by R. Mansell and M. Raboy, 366-382. Chichester: Wiley-Blackwell, 2011.

Andreasson, S. "Orientalism and African development studies: The 'reductive repetition' motif in theories of African underdevelopment". Third World Quarterly 26 no 6 (2005), 971-986.

Bandelj, N. and F. Wherry, eds. The Cultural Wealth of Nations. Stanford, CA: Stanford University Press, 2011.

Banks, N. and D. Hulme. "New development alternatives or business as usual with a new face? The transformative potential of new actors and alliances in development," this special issue. 
Barnett C., P. Cloke, N. Clarke, and A. Malpass. "Consuming ethics: Articulating the subjects and spaces of ethical consumption". Antipode 37 (2005): 23-45.

Barnett C., P. Cloke, N. Clarke, and A. Malpass. Globalizing Responsibility: The Political Rationalities of Ethical Consumption. Oxford: Blackwell, 2010.

Berglind M., and C. Nakata. Cause-related marketing: More buck than bang? Business Horizons 48 no 3 (2005): 443-453.

Blowfield, M. and C. S. Dolan. "Business as a development agent: evidence of possibility and improbability", this special issue.

Blowfield, M. "Reasons to be cheerful? What we know about CSR's impact". Third World Quarterly 28 no 4 (2007), 683-695.

Boykoff, M. and M.K. Goodman. "Conspicuous redemption: Promises and perils of celebrity involvement in climate change". Geoforum 40 (2009): 395-406

Brockington, D. "The production and construction of celebrity advocacy in international development", this special issue.

Brockington, D. Celebrity and the Environment: Fame, Wealth and Power in Conservation. London: Zed Books, 2009.

Budabin, A. C. "Diasporas as development partners for peace? The alliance between the Darfuri diaspora and the Save Darfur Coalition", this special issue.

Butt, L. "The suffering stranger: Medical anthropology and international morality". Medical Anthropology 21 no 1 (2002): 1-24.

Calderisi, R. The Trouble with Africa: Why Foreign Aid Isn't Working. New York: Palgrave, 2006.

Carrier, J.G. "Introduction", in Ethical Consumption: Social Value and Economic Practice, edited by J.G. Carrier and P.G. Luetchford. New York and London: Berghan, 2012

Carrier, J.G. and P.G. Luetchford, eds. Ethical Consumption: Social Value and Economic Practice. New York and London: Berghan, 2012.

Carroll, A.B. "Corporate Social Responsibility: Evolution of a definitional construct". Business and Society, 38 no 3 (1999): 268-295.

Cimoli, M., G. Dosi and J. Stiglitz., eds. Industrial Policy and Development: The Political Economy of Capabilities Accumulation. Oxford: Oxford University Press, 2009.

Clarke, N. "From ethical consumerism to political consumption". Geography Compass 2 (2008): 1870-1884.

Clarke, N., C. Barnett, P. Cloke, and A. Malpass. "Globalising the consumer: doing politics in an ethical register". Political Geography 26 (2007): 231-249.

Collier, P. The Bottom Billion: Why the Poorest Countries are Failing and What Can Be Done About It. Oxford: Oxford University Press, 2007.

Cooper, A.F. "Beyond one image fits all: Bono and the complexity of celebrity diplomacy". Global Governance 14 (2008): 265-272.

Corbridge, S. "The (im)possibility of development studies". Economy and Society 36 (2007): 179-211.

Crush, J. Power of Development. London: Routledge, 1995.

Devinney, T., P. Auger, and G.M. Eckhardt, eds. The Myth of the Ethical Consumer. Cambridge: Cambridge University Press, 2010.

de Waal, A. "The humanitarian carnival". World Affairs Fall (2008): 43-55.

Easterly, W. The White Man's Burden: Why the West's Efforts to Aid the Rest Have Done So Much Ill and So Little Good. New York: Penguin, 2006. 
Escobar, A. Encountering Development: The Making and Unmaking of the Third World. Princeton, NJ: Princeton University Press, 1995.

Fassin, D. When Bodies Remember: Experiences and Politics of AIDS in South Africa. Berkeley and Los Angeles, CA: University of California Press, 2007.

Ferguson, J. The Anti-Politics Machine: "Development”, Depoliticization and Bureaucratic Power in Lesotho. Minneapolis, MN: University of Minnesota Press, 1994.

Ferguson, J. Expectations of Modernity: Myths and Meanings of Urban Life on the Zambian Copperbelt. Berkeley and Los Angeles, CA: University of California Press 1999.

Gibbon, P., S. Ponte and E. Lazaro, eds. Global Agro-food Trade and Standards: Challenges for Africa. Basingstoke: Palgrave, 2010.

Goodman, M.K. and C. Barnes. "Star/poverty space: the making of the 'development celebrity" Celebrity Studies 2 no 1 (2011): 68-85.

Hall, S. "The West and the rest". In Formations of Modernity, edited by S. Hall. London: The Open University, 2011.

Hansen, H. and F. Tarp. "Aid effectiveness disputed". Journal of International Development 12 no 3 (2000): 375-398.

Harrison, G. "Debt, Development and Intervention in Africa: The Contours of a Sovereign Frontier". Journal of Intervention and Statebuilding 1 no 2 (2007): 189-209.

Harrison, G. "Campaign Africa: Exploring the Representation of Africa and Its Role in British Identity". The British Journal of Politics and International Relations, DOI: 10.1111/j.1467-856X.2012.00520.x.

Hood, J. "Celebrity philanthropy: The cultivation of China's HIV/AIDS heroes". In Celebrity in China, edited by L. Edwards and E. Jeffreys. Hong Kong: Hong Kong University Press, 2009.

Idemudia, U. "Corporate social responsibility and developing countries: Moving the critical CSR Research Agenda in Africa Forward." Progress in Development Studies 11 no 1 (2011): 1-18.

Kapoor, I. Celebrity Humanitarianism: The Ideology of Global Charity. London: Routledge, 2012.

Keck, M.E., and K. Sikkink. Activists Beyond Borders: Advocacy Networks in International Politics. Ithaca, NY: Cornell University Press, 1998.

King, S. Pink Ribbons, Inc.: Breast Cancer and the Politics of Philanthropy. Minneapolis, MN: University of Minnesota Press, 2006.

Kothari, U. "Critiquing 'race' and racism in development discourse and practice". Progress in Development Studies 6 no 1 (2006): 1-7.

Kothari, U. "Commentary: History, time and temporality in development discourse". In History, Historians and Develoment Policy. A Necessary Dialogue, edited by C. A. Bayly et al., 65-70. Manchester: Manchester University Press, 2006.

Kothari, U. "Trade, consumption and development alliances: The historical legacy of the Empire Marketing Board poster campaign", this special issue.

Kragelund, P. “'Donors go back home': Non-traditional state actors and the creation of development space in Zambia", this special issue.

Lin, J.Y. New Structural Economics: A Framework for Rethinking Development and Policy. Washington DC: World Bank, 2012.

Littler, J. "II feel your pain': Cosmopolitan charity and the public fashioning of the celebrity soul". Social Semiotics 18 (2008): 237-251. 
Lorde, A. Sister Outsider. Berkeley, CA: The Crossing Press, 1984.

McGoey, L. "The Philanthropic State: Market-state hybrids in the philanthrocapitalist turn", this special issue.

Miller, D. The Dialectics of Shopping. Chicago: University of Chicago Press, 2001.

Mills, G. Why Africa Is Poor: And What Africans Can Do about It. London: Penguin Books, 2010.

Moyo, D. Dead Aid: Why Aid Is not Working and How There Is Another Way for Africa. London: Allen Lane, 2009.

Nair, S. "Governance, representation and international aid". Third World Quarterly 34 no 4 (2013): 630-652.

Nederveen Pieterse, J. White on Black: Images of Africa and Blacks in Western Popular Culture. New Haven: Yale University Press, 1992.

Nederveen Pieterse, J. Development theory. Deconstructions/reconstructions. London: Sage Publications, 2001.

Nederveen Pieterse, J. Globalization and Culture: Global Mélange. New York: Rowman \& Littlefield, 2003.

Newell, P. and J.G. Frynas. "Beyond CSR? Business, poverty and social justice: an introduction". Third World Quarterly 28 no 4 (2007): 669-681.

Newell, P. "CSR and the limits of capital". Development and Change 39 no 6 (2008): 1063-1078.

Noman, A. and J. Stiglitz, eds. Good Growth and Governance in Africa: Rethinking Development Strategies. Oxford: Oxford University Press, 2012.

Ponte, S. and L.A. Richey. "Buying into development? Brand aid forms of causerelated marketing", this special issue.

Prahalad, C.K. The Fortune at the Bottom of the Pyramid: Eradicating Poverty through Profits. Upper Saddle River, NJ: Wharton School Publishing, 2005.

Richey, L.A. and S. Ponte, S. Brand aid: Shopping well to save the world. Minneapolis, MN: University of Minnesota Press, 2011.

Riddell, R. Does foreign aid really work? Oxford: Oxford University Press, 2007.

Robbins, J.R. "Beyond the Suffering Subject: Toward an Anthropology of the Good" Journal of the Royal Anthropological Institute (19) (2013): 447-462.

Rodrik, D. One economics, many recipes: Globalization, institutions and economic growth. Princeton: Princeton University Press, 2007.

Sachs W. The Development Dictionary. London: Zed Books, 1992.

Sachs, J.D. The End of Poverty: Economic Possibilities of Our Time. London and New York: Allen Lane, 2005.

Sandbrook, R. and J. Barker. The Politics of Africa's Economic Stagnation. Cambridge: Cambridge University Press, 1985.

Schuurman, F.J. "Critical development theory: Moving out of the twilight zone". Third World Quarterly 30 no 5 (2009): 831-848.

Slater, D. Consumer Culture and Modernity. London: Polity, 1997.

Smith, M.B. and H. Yanacopulos, eds. Special Issue: The Public Faces of Development. Journal of International Development 16 no 5 (2004): 657-749.

Sylvester, C. "Development and postcolonial studies: Disparate tales of the 'third world". Third World Quarterly 20 (1999): 703-21.

Tarp, F., ed. Foreign Aid and Development: Lessons Learnt and Guidelines for the Future. London and New York: Routledge, 2000.

Tierney, M.J., D.L. Nielson, D.G. Hawkins, J.T. Roberts, M.G. Findley, R.M. Powers, and B. Parks. "More dollars than sense: Refining our knowledge of 
development finance using AidData”. World Development 39 no 11 (2011): 1891-1906.

Trentmann, F. "An introduction: Knowing consumers--Histories, identities, practices". In The Making of the Consumer: Knowledge, Power and Identity in the Modern World, edited by F. Trentmann. Oxford: Berg, 2006.

van de Walle, N. African Economies and the Politics of Permanent Crisis, 1979-1999. Cambridge: Cambridge University Press, 2001.

Wade, R. "Accountability gone wrong: The World Bank, NGOs, and the US government in a fight over China". New Political Economy 14 no 1 (2009): 2548.

Wartick, S.L., and P.L. Cochran. "The evolution of the corporate social performance model". The Academy of Management Review 10 no 4 (1995): 758-769.

Whitfield, L. and L. Buur. "The politics of industrial policy: Ruling elites and their alliances, this special issue.

Woolcock, M., S. Szreter and V. Rao. "How and Why Does History Matter for Development Policy?" Journal of Development Studies 47 no 1 (2011): 70-96. 